\title{
PAH, PCB, TPH and Mercury in Surface Sediments of the Delaware River Estuary and Delmarva Peninsula, USA
}

A.W. Kim¹, C.H. Vane ${ }^{1}$, V. Moss-Hayes ${ }^{1}$, S.E. Engelhart ${ }^{2}$, A.C. Kemp ${ }^{3}$

${ }^{1}$ British Geological Survey, Kingsley Dunham Centre, Keyworth, Nottingham, NG12 5GG, UK

2Department of Geosciences, University of Rhode Island, 9 East Alumni Avenue, Kingston, RI 02881, USA

${ }^{3}$ Department of Earth and Ocean Sciences, Tufts University, Medford, MA 02155, USA

${ }^{*}$ Corresponding author. Tel+44 (0)115 936 3324; fax+44 (0)115 936 3460. E-mail address: awk@bgs.ac.uk 


\begin{abstract}
Surface sediment concentrations of polycyclic aromatic hydrocarbons (PAH) and polychlorinated biphenyls (PCB), total petroleum hydrocarbons (TPH) and mercury, were compared from two areas with contrasting land use history, the industrial Delaware Estuary and the rural Delmarva Peninsula (USA). TPH in the Delaware (38-616 mgkg-1) and saturate / aromatic fractions suggested petroleum/industrial sources compared to biogenic sources in the Delmarva coastal control $(<34-159$ mgkg-1). Within the Delaware the $\sum$ PAH18 ranged from 3749-22324 $\mu g k g-1$ with isomeric ratios indicative of petroleum combustion source/s, conversely, those in the Delmarva (5-2139 $\mu \mathrm{gkg}-1)$ also yielded relatively higher perylene that were consistent with natural background levels derived from vegetation/coal combustion source/s. $\sum \mathrm{PCB}$ (tri-hepta) concentrations in the Delmarva (0.6-6.5 $\left.\mu \mathrm{gkg}-1\right)$ were less than the threshold effect concentration (TEC), whereas the Delaware had received much higher PCB loading (18.1-136.8 $\mu \mathrm{gkg}-1)$ as evidenced by a significantly higher amounts in some samples (>TEC).
\end{abstract}


Diffuse pollution from urban-residential run-off and industrial discharges can adversely impact river, salt-marsh and tidal-creek sediment quality (Barrett and McBrien, 2007; Fox et al., 2001; lannuzzi et al., 1995; Long et al., 1995; Sanger et al., 2004; Vane et al., 2008; White et al., 2005). Point source pollution from shipping (e.g. fuel discharge) can also impact rivers and salt marshes (White et al., 2005). Due to their negative effect on flora and fauna, the contaminants of greatest concern in these environments are mercury $(\mathrm{Hg})$, and persistent organic pollutants (POPs) such as polycyclic aromatic hydrocarbons (PAHs) and polychlorinated biphenyls (PCBs). Bioaccumulation of contaminants in organisms that are part of a detritus-driven food web is a potential health hazard if pollutants are concentrated and subsequently consumed by humans. Once sorbed to the sediment, PAHs and PCBs also accumulate in the leaves and roots of standing and decaying salt-marsh plants (e.g. Spartina alterniflora), which are an important food source for the base of the detrital salt marsh food chain (Mrozek et al., 1983; Wall et al., 2001). Bioaccumulation of POPs to higher trophic levels occurs by a combination of lipid-water partitioning and dietary accumulation processes as well as other food-web specific routes (Connolly and Pedersen, 1988; Kelly et al., 2007). Also, organic pollutants at high concentrations can cause growth impairment of halophytic plants, which in turn may limit buffering of storm events and stabilisation of coastal sediments (Mrozek et al., 1983; Watts et al., 2006)). Therefore monitoring of sediment-hosted organic pollutants is important to ensure the protection of populations that consume species of fish and shell fish.

Estuary sediments and salt marshes on the east coast of the USA are potentially important sinks for POPs due to preferential adsorption of pollutants to organic matter (Fox et al., 2001; Scrimshaw and Lester, 2001). In this study we examine the sediments from an urban (the Delaware River Estuary) and rural (Delmarva Peninsula) setting to: (1) determine individual concentrations of $\mathrm{Hg}$, total (non-volatile) petroleum hydrocarbons (TPH), PAHs and PCBs, (2) identify, where possible, sources of pollution and related spatial gradients of contaminants, (3) compare the contaminant concentrations to published sediment quality guideline values (SQGs) to evaluate their possible impact upon ecological habitats. This dataset provides a baseline for long-term ecosystem monitoring and assessment of the impact of future pollution events. 
The study areas chosen were a $\sim 130 \mathrm{~km}$ length of the Delaware Estuary (Figure 1) and a $\sim 100 \mathrm{~km}$ length of the Delmarva Peninsula, from Chincoteague to its southern most point, Kiptopeke, along the Atlantic coast (Figure 2).

The Delaware Estuary is $\sim 200 \mathrm{~km}$ long from Trenton to the eastern seaboard of the U.S.A., however, the Delaware River extends a further $474 \mathrm{~km}$ north from Trenton and the combined estuary-river catchment area is $36,570 \mathrm{~km}^{2}$ that encompasses five U.S. states (New York, New Jersey, Pennsylvania, Maryland and Delaware). It flows into the Delaware Bay and finally into the Atlantic Ocean. The zone of this study extends from Artificial Island $(80 \mathrm{~km}$, from the Atlantic Ocean) to Trenton $(214 \mathrm{~km})$. This area includes the variable salinity transition zone (0-18 psu) from 80 to $129 \mathrm{~km}$ which is characterised by high turbidity and low biological productivity. Along this $130 \mathrm{~km}$ stretch, it flows through the heavily industrial and urbanised area of Philadelphia, PA and Wilmington, DE. The Delaware Estuary has a history of diffuse and point-source pollution (Church et al., 2006; Hall and Burton, 2005; Sutton et al., 1996; Tarr and McCurley, 1984).

The Delmarva Peninsula is located $\sim 120 \mathrm{~km}$ south from the mouth of Delaware Bay. The watershed of the peninsula flows either west into the Chesapeake Bay or east towards the Atlantic Ocean via tidal creeks and salt marshes. The peninsula borders the Atlantic by a complex changing barrier of low lying islands, shallow bays, lagoons and sand banks (Kastler and Wiberg, 1996) and the land-use is predominantly rural and agricultural. Coastal regions, such as this peninsula, are currently under pressure from population growth and subsequent development (Culliton et al., 1990). Development of these watersheds, especially those surrounding tidal creek-salt marshes, can potentially increase point and nonpoint source pollution inputs into these ecosystems.

These two contrasting sites were chosen to demonstrate the differences in mercury and organic contaminants between, an area heavily impacted by urban / industrial activity and a less impacted area in a rural environment. 
Surface sediments $(0-1 \mathrm{~cm})$ were collected from the intertidal zone at low tide from the Delaware Estuary shore (Pennsylvania, New Jersey USA, April 2010) and salt marshes on the Delmarva Peninsula (Virginia, USA, June 2008) using a clean, stainless steel trowel (Figure 1, Figure 2, Table 1). Sediments were sealed in polyethylene plastic bags and transported in a cool box at $\sim 4^{\circ} \mathrm{C}$, then immediately frozen at $\sim-20^{\circ} \mathrm{C}$. In the laboratory, an aliquot of each ( $\sim 500 \mathrm{~g})$ sediment was freeze-dried, sieved to $<2 \mathrm{~mm}$ and ground to a fine powder (Beriro et al., 2014).

Total organic carbon (TOC) content was determined using an Elementar VarioMax C, N analyser after acidification with $\mathrm{HCl}(50 / 50 \mathrm{v} / \mathrm{v})$ to remove carbonate. The limits of quantification (LOQ) reported for a typical $300 \mathrm{mg}$ sample were $0.18 \%$.

Total (non-volatile) petroleum hydrocarbons (TPH) were determined using a thin layer chromatography - flame ionization detector (TLC-FID). $8 \mathrm{~g}$ of sediment was extracted using an ASE 200, Dionex accelerated solvent extraction (dichloromethane:acetone 1:1 $\mathrm{v} / \mathrm{v}, 100^{\circ} \mathrm{C}, 1500$ p.s.i.). The resulting extract was reduced in volume / dried using a Turbovap $^{\circledR}$ (dry nitrogen, $30^{\circ} \mathrm{C}$ ) and reconstituted in toluene $(1.0 \mathrm{~mL})$. A $1.2 \mu \mathrm{L}$ aliquot of this was spotted onto silica Chromrods ${ }^{\circledR}$. The saturated and aromatic hydrocarbons were separated by developing the rods for $21 \mathrm{~min}$ in $n$-hexane and then for 8 min in toluene. The concentration of each fraction was determined using an latroscan ${ }^{\circledR}$ Mk6s instrument. The limit of quantification (LOQ) for total non-volatile hydrocarbons was 3 $\mathrm{mg} / \mathrm{kg}$.

Total mercury was determined using a DMA-80 dry solid sample analyser (Milestone, c/o Analytix Ltd, South Tyneside, UK). Operated at $650^{\circ} \mathrm{C}$ and calibrated at $1-20 \mathrm{ng}$ (9 duplicate points) in duplicate and 30-200ng (5 single points). Two different certified reference materials were determined in duplicate sample in every ten analyses as a quality control. Data for the lower value certified reference material (CRM) is presented in Table 1. The limit of quantification (LOQ) for $\mathrm{Hg}$ was $0.02 \mathrm{mg} / \mathrm{kg}$ (calculated from a blank where $n=9$ ).

High pressure liquid chromatography (HPLC) was used to determine PAH concentrations in the Delmarva sediments (Vane et al., 2007; Vane et al., 2008) and gas chromatography mass spectrometry (GCMS) was used to measure PAHs in the Delaware sediments. For the GCMS method, $1 \mathrm{~g}$ sample was spiked with: naphthalene- $d^{8}$, biphenyl- $d^{10}$, phenanthrene- $d^{10}$, pyrene- $d^{10}$, benzo[a]athracene- $d^{10}$, benzo[a]-pyrene- $d^{12}$ and benzo[g,h,i]perylene- $d^{12}$ of between 267 and $4000 \mu \mathrm{g} / \mathrm{kg}$ dry/wt. and extracted using ASE (hexane/acetone $1: 1 \mathrm{v} / \mathrm{v}, 100^{\circ} \mathrm{C}, 2000$ p.s.i.). Extracts were reduced to $0.25 \mathrm{~mL}$, and transferred to a solid phase extraction (SPE) cartridge (Bond Elut, TPH, W500MG, Na2SO4). The first fraction was eluted with pentane $(0.5+1$ $\mathrm{mL})$, the second with $6 \mathrm{~mL}$ hexane/iso-propanol $(97: 3 \mathrm{v} / \mathrm{v})$ and reduced to $0.2-1.0 \mathrm{~mL}$. Concentrations of PAH were measured using a Varian 3800 gas chromatograph (GC) fitted with a VF35ms column, 30m, 0.25mm i.d., $0.1 \mu \mathrm{m}$ df (Agilent Technologies, Stockport, UK) coupled to a Varian 1200L triple quadropole mass spectrometer operating in full scan mode (ionisation energy $70 \mathrm{eV}$, mass range 47-500 amu). Quality control was achieved by subjecting a certified reference material, NRCHS5 Harbour Sediment, (Table 2) to the above procedure. A procedural blank prepared from $1 \mathrm{~g}$ silica (Sigma Aldrich, UK) - a material devoid of PAH - was treated in a similar way. LOQs 
were determined by peak height at 5 times signal / background ratio of the procedural blank and are presented in Table 2.

PCB concentrations were determined as follows: samples $(10 \mathrm{~g})$ were spiked with PCB $34,62,119,131$ and $173(9.0-9.7 \mathrm{ng} / \mathrm{g})$ and PCB 19 and 147 (7.9-10.1 ng/g) and extracted using ASE, reduced in volume to $3-4 \mathrm{~mL}$ followed by addition of concentrated $\mathrm{H}_{2} \mathrm{SO}_{4}(3 \times 0.6 \mathrm{~mL})$ and agitated. The acidic aqueous layer was immediately removed, any remaining moisture was removed by passing the organic layer through a glass Pasteur pipette containing anhydrous $\mathrm{Na}_{2} \mathrm{SO}_{4}$. The hexane extract was reduced to $0.3-0.25 \mathrm{~mL}$ and subjected to the same SPE method as for PAH, spiked with PCB 29 and 157 $(3.1-3.3 \mathrm{ng} / \mathrm{g})$ and reduced to $0.1-0.2 \mathrm{~mL}$. Concentrations of PCB were measured using GCMS fitted with a DB1 column, $60 \mathrm{~m}, 0.25 \mathrm{~mm}$ i.d., $0.1 \mu \mathrm{m}$ df (Agilent Technologies, Stockport, UK). The MS was operated in selected ion mode $(\mathrm{m} / \mathrm{z} 71,220,256,258,290$, $292,326,328,360,362,394,396)$ with a scan time of $0.5 \mathrm{~s}$. Congener profile distributions for tri to hepta-chlorinated biphenyls were determined using 5 separate individual relative response factors for each congener group. A standard consisting of $2 \times 5$ individual PCBs based on first and last eluting congener was used to define the 'retention time window' for each group. The sum of these 5 groups is $\sum$ PCB(tri-hepta) and $\sum$ 7PCB comprised congeners 28, 52,101, 118, 153, 138, 180.

Quality control was achieved by subjecting a PCB certified reference material EC-1, PCBs in harbour sediment to the above procedure and analysing it by the same method as for the samples (Table 3). A procedural blank prepared from silica (Sigma Aldrich, UK) - a material devoid of PCBs was treated in a similar way. 
Mercury is one of the most important heavy metal pollution indicator in estuarine and coastal sediments, due to its toxic effect on marine invertebrates and tendency for the methyl-Hg to bio-accumulate up trophic levels, where it can enter humans via the ingestion of fish and shellfish (Bigham et al., 2006; Boening, 2000). An upstream to downstream spatial trend of $\mathrm{Hg}$ was observed in the Delaware River Estuary sediments (Figure 3). Hg concentrations upstream from Trenton North (sites 13-16) had low values of $<0.1 \mathrm{mg} / \mathrm{kg}$. Hg concentrations were elevated $(0.18-0.28 \mathrm{mg} / \mathrm{kg})$ from Carney Point to Reedy Point (sites 17-19), but returned to lower values $(<0.1 \mathrm{mg} / \mathrm{kg}$ ) downstream at Elfsborg to Augustine Beach (sites 20-21).

The Delaware sediments had higher $\mathrm{Hg}$ concentrations, mean $0.13 \mathrm{mg} / \mathrm{kg}$, compared to Delmarva, mean $0.07 \mathrm{mg} / \mathrm{kg}$ (Table 1). These sediment-hosted $\mathrm{Hg}$ concentrations were indicative of natural background conditions and did not exceed $\mathrm{Hg}$ effects range median (ERM) limit of $0.71 \mathrm{mg} / \mathrm{kg}$ (Long et al., 1995), or the probable effects level (PEC) limit of $1.06 \mathrm{mg} / \mathrm{kg}$ (MacDonald et al., 2000) for marine and estuarine ecosystems, which according to these criteria, indicates that $\mathrm{Hg}$ may not be impacting the aquatic organisms in these regions. The highest concentration observed at sites 17-19 (Figure 1) are above the threshold effects concentration (TEC) and the effects range low (ERL) (Table 1); below these values, adverse effects on biota are not expected to occur.

The higher concentrations of $\mathrm{Hg}$ in Delaware River Estuary sediments compared to those from the Delmarva Peninsula likely reflects sedimentary input from urban and industrial areas along the Delaware River Estuary compared to the rural Delmarva watershed. A plausible cause for the elevated concentrations from Carney Point to Reedy Point (sites 17, 18, and 19) on the Delaware River Estuary is that it may come from the diffuse source of numerous heavy industry and waste processing activities (vehicle scrap yards) in the vicinity of Wilmington. A similar spatial trend was observed in the Thames River Estuary, UK where total $\mathrm{Hg}$ ranged from 0.01 to $12.07 \mathrm{mg} / \mathrm{kg}$ (mean $=2.10 \mathrm{mg} / \mathrm{kg} ; \mathrm{n}=351$ ) and the highest concentrations were found close to likely point sources of industrial pollution (Vane et al., 2015). Alternatively, differences in $\mathrm{Hg}$ concentration between the two current study regions may arise from differences in sediment characteristics and dynamics (i.e. river estuarine and coastal oceanic). Total $\mathrm{Hg}$ is more strongly correlated to TOC in the Delaware $\left(R^{2} 0.6372\right)$ compared to the Delmarva $\left(R^{2} 0.5194\right)$, suggesting that organic matter is one of the controlling factors of $\mathrm{Hg}$ sorption. The correlation difference between the two sites may be partly explained by a lower availability of $\mathrm{Hg}$ to sorb in the Delmarva sediments, but other factors such as grain size, bacteria and mineral colloids are also important in fixing $\mathrm{Hg}$ in the environment (Haitzer et al., 2003).

Worldwide, marine coastal and estuarine sediments have $\mathrm{Hg}$ background concentrations of approximately 0.02 to $0.1 \mathrm{mg} / \mathrm{kg}$ (Kannan and Falandysz, 1998; Shi et al., 2007). The low concentrations of the Delmarva are similar to those found in other salt marshes such as Barnegat Bay - Little Egg Harbour Estuary, NJ, which ranged from $<0.02$ to $2.61 \mathrm{mg} / \mathrm{kg}$, mean $0.31 \mathrm{mg} / \mathrm{kg}$ (Vane et al., 2008) and in South Carolina coastal estuaries which ranged from 0.02 to $0.13 \mathrm{mg} / \mathrm{kg}$, mean $0.07 \mathrm{mg} / \mathrm{kg}$ (Sanger et al., 1999a). Delaware and Delmarva Hg concentrations are considerably lower than in sediments from waterways in the industrialized Passaic River (New Jersey) which ranged from 0.91 to $5.80 \mathrm{mg} / \mathrm{kg}$, mean $2.70 \mathrm{mg} / \mathrm{kg}$ (Armstrong et al., 2005) and the Mersey Estuary, UK at a mean concentration of $0.84 \mathrm{mg} / \mathrm{kg}$ for surface sediments (Vane et al., 2009). In this current study, the $\mathrm{Hg}$ concentrations observed in the Delaware River Estuary are similar to those previously reported for surface sediments collected 
from the Mullica River which varied from $0.24-0.46 \mathrm{mg} / \mathrm{kg}$, mean $0.32 \mathrm{mg} / \mathrm{kg}$ (Armstrong et al., 2005). The Mullica River (New Jersey, USA) was used as a reference area for regional background concentrations of metals in the absence of significant anthropogenic input; according to this criteria total the $\mathrm{Hg}$ concentrations found in the Delaware Estuary (current study), are within regional background levels. 
Total (extractable, non-volatile) petroleum hydrocarbon (TPH) concentrations in surface sediments are presented in Table 1. The Delaware TPH mean was $271 \mathrm{mg} / \mathrm{kg}$ which is significantly higher than the Delmarva, where the mean was $86 \mathrm{mg} / \mathrm{kg}$. Previous studies have found that in pristine estuarine and intertidal sediments total hydrocarbon concentrations range from about 0.5 to $10 \mathrm{mg} / \mathrm{kg}$ and can be as high as 30 $\mathrm{mg} / \mathrm{kg}$, where there is significant input from $n$-alkanes sourced from plant waxes for example (Volkman et al., 1992; Volkman and Nichols, 1991). The values of the Delaware are broadly comparable to that from a study of salt marsh surface sediments of Barnegat Bay-Little Egg Harbor Estuary, New Jersey, where mean TPH was 231 $\mathrm{mg} / \mathrm{kg}$ (Vane et al., 2008).

Sediments containing total TPH $>100 \mathrm{mg} / \mathrm{kg}$ are generally considered to have received some petroleum pollution and sediments with values $>500 \mathrm{mg} / \mathrm{kg}$ are indicative of significant petroleum inputs (Volkman et al., 1992; Volkman and Nichols, 1991). Using these criteria for the Delmarva, all twelve sites had TPH values that suggested minimal levels of petroleum contamination. The low hydrocarbon values at all sites (with the exception of sites 2 and 12) probably represent background hydrocarbons derived from biological sources such as the dominant salt marsh plants, namely cord grasses (Spartina patens and S. alterniflora) and possibly other sources such as animals as well as micro and macroalgae (Volkman et al., 1992). The range of hydrocarbon concentrations encountered in the Delmarva, are consistent with biologically derived hydrocarbon source augmented by low levels anthropogenic hydrocarbon contamination. This rationale can be substantiated further because the Delmarva sediments were dominated by saturates (mean $72 \%$ ), as compared to aromatic hydrocarbons (mean 28\%), whereas in the Delaware the aromatics were in greater abundance (mean 40\%), compared to the saturates of mean $60 \%$ (Table 1 ). A possible explanation for this difference is that the Delmarva has a larger input of saturates derived from the waxy cuticle of terrestrial and aquatic plants, whereas in contrast, due to the low biological productivity of the transitional zone (McLusky and Elliott, 2004) there is a lower input of theses plant derived saturates and that it receives sedimentary input from urban and industrial sources containing aromatic compounds. Using the same criteria for the Delaware, seven of nine sites had TPH values that suggested only some petroleum contamination. However, for Carney Point (site 17) and Deeves Beach (site 18) the TPH (543 and $616 \mathrm{mg} / \mathrm{kg}$ respectively) suggests significant petroleum input within this $5 \mathrm{~km}$ stretch of the river-estuary. This is not surprising as this section is in close proximity of areas of heavy industry which may be a possible source of diffuse contamination. Possible sources could be: the Port of Delaware (shipping and fuel storage) situated on the western bank of the Delaware at the tributary of the Christina River; the DuPont Chambers Plant at Deepwater (chemical manufacturing) on the eastern bank; the Croda plant (manufacture of lubrication oils) situated on the southern side of the Delaware Memorial Bridge; and historic records of oil refinery effluent discharge into the Delaware, notably from the Motiva refinery situated $5 \mathrm{~km}$ north of the Chesapeake-Delaware Canal (Alexander et al., 2005; Hall and Burton, 2005; Uhler et al., 2005).

In a study of comparable rivers (that flow through eastern U.S. industrial zones) and catchments, in the Newark Bay, New Jersey area (Huntley et al., 1995) the mean sediment TPH concentrations were: Arthur Kill River, 703 mg/kg (median 205 mg/kg); Hachensack River, 119 mg/kg (median 106 mg/kg); Passaic River 1520 mg/kg (median $294 \mathrm{mg} / \mathrm{kg}$ ). These concentrations are broadly comparable to those reported in the current study (Table 1). 
PAHs are derived from four broad sources: biogenic, geogenic, petrogenic and pyrolytic (formed during the combustion of organic matter and fossil fuels); their environmental distribution and attenuation have been extensively documented (Boehm, 2006; Sanger et al., 1999b).

PAH concentrations in the Delaware are significantly higher than the Delmarva

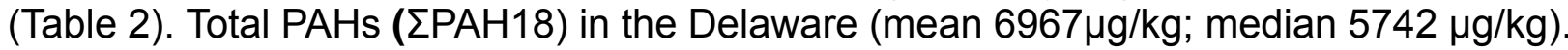
Whereas in the Delmarva the mean was $485 \mu \mathrm{g} / \mathrm{kg}$ and the median $170 \mu \mathrm{g} / \mathrm{kg}$ ). The sediment quality guidelines (SQGs) for total PAHs for the effects range median (ERM) limit is $44792 \mu \mathrm{g} / \mathrm{kg}$ (Long et al., 1995) and the probable effect concentration (PEC) limit is $22800 \mu \mathrm{g} / \mathrm{kg}$ (MacDonald et al., 2000) for marine and estuarine ecosystems. This indicates that the PAH concentrations, in both study areas, is unlikely to have no possible adverse effect on aquatic organisms in this area. In the current study, the ¿PAH18 concentrations (not total PAHs) were indicative of natural background for both the Delaware and Delmarva (Table 2). The range and mean of values of the Delmarva are broadly comparable to those from a study of salt marsh surface sediments of Barnegat Bay-Little Egg Harbor Estuary, New Jersey, where $\Sigma$ PAH18 was 37-1696 $\mu \mathrm{g} / \mathrm{kg}$ with a mean value of $671 \mu \mathrm{g} / \mathrm{kg}$ (Vane et al., 2008). The Delmarva $\Sigma$ PAH18 are also comparable with those reported for contaminants in surface sediments taken from the mudflats of the Mullica River, New Jersey, that has been relatively unaffected by industrial and urban influences (lannuzzi et al., 2005), where $\Sigma$ PAH25 concentrations were $436-1380 \mu \mathrm{g} / \mathrm{kg}$ with a mean of $786 \mu \mathrm{g} / \mathrm{kg}$. In the current study, the mean concentration is marginally lower $(485 \mu \mathrm{g} / \mathrm{kg})$ than that reported by lannuzzi et al., 2005 and can be mitigated by the fact that we report $\Sigma \mathrm{PAH} 18$ rather than $\Sigma \mathrm{PAH} 25$.

The $\Sigma$ PAH18 concentrations in the Delaware study area from Reedy Point (site 19) to Augustine Beach (site 21) were lower $(2355-3030 \mu \mathrm{g} / \mathrm{kg}$ ) than at sites further upstream from Trenton North (site 13) to Carney Point (site 17) $(3749-7907 \mu \mathrm{g} / \mathrm{kg}$ ). A possible source for these higher concentrations, in this stretch, is delivery of PAH-laden sediment from the Schuylkill River, where there is a large industrial cluster of refineries, a naval base, an international airport, and vehicle breakers yards. The PAH concentrations of the current study seems to be in agreement with previous studies that found PAH in sediment traps from both the Delaware and Schuylkill Rivers to be 5120 $\mu \mathrm{g} / \mathrm{kg}$ and $5150 \mu \mathrm{g} / \mathrm{kg}$ respectively (Pohlman et al., 2002); they also discussed the movement sediment along the tidal incursion zone at the intersection of both rivers. The lower PAH concentration observed downstream in this study (sites 19-20) could probably be attributed to sediment dilution or mixing affect with less contaminated sediment.

The $\Sigma$ PAH 18 values found at sites clustered in the vicinity of the Motiva refinery and C\&D Canal (sites 19-21) in the Delaware were 2355-3030 $\mathrm{\mu g} / \mathrm{kg}$ (Table 2) and are similar to those found by other workers in the same study area (Alexander et al., 2005) where the total PAH concentrations from two sediment cores were $3100-3200 \mu \mathrm{g} / \mathrm{kg}$ at $4-6.5 \mathrm{~cm}$ depth, they attributed this to be consistent with historic sediment PAH inputs in such an industrial river system. Approximately $17 \mathrm{~km}$ north of this cluster is the PAH 'hot-spot' of Deeves Beach (site 18) where $\Sigma$ PAH18 was $22324 \mu \mathrm{g} / \mathrm{kg}$ which also had the highest $\mathrm{Hg}$ concentration of all the sites at $383 \mathrm{mg} / \mathrm{kg}$ (Table 1). As explained earlier, one probable reason for these elevated PAH concentrations at this site, is that it is from the numerous heavy industrial activities in the vicinity, road run-off and the sedimentary outflow from the Christina River which sorb to the relatively high TOC (9.05\%) contained in this sediment. It was found that $\Sigma \mathrm{PAH} 18$ is strongly correlated to TOC in the Delaware River Estuary sediment $\left(R^{2}\right.$ 0.7353) compared to the Delmarva salt marsh 
where no correlation was observed $\left(R^{2} 0.0068\right)$, this poor correlation was also observed in the salt marshes of Barnegat Bay - Little Egg Harbor Estuary $\left(R^{2} 0.22\right)$ by Vane, et al. (2008).

The mean proportion of perylene to $\mathrm{EPAH} 18$ in the Delmarva sediments was $14 \%$, this was higher than those from the Delaware at 5\% (Table 2). Perylene is a diagenetic product derived from natural precursors during early diagenesis (Conde et al., 2005; Silliman et al., 1998; Venkatesan, 1988; Wilcke, 2007) and formed in situ in river sediments (Luo et al., 2008), however only trace amounts of perylene are produced during combustion (Gonzalez-Perez et al., 2004; Kakareka and Kukharchyk, 2003). Previous workers (Vane et al., 2013) have demonstrated that perylene was one of the predominant PAHs in five species of upland vegetation and had a greater relative abundance $(10-18 \%)$ than is usually observed in particles/sediments $(<2 \%)$ receiving $\mathrm{PAH}$ of anthropogenic / pyrolytic origin. Therefore a possible explanation for the higher proportion of perylene in the Delmarva sediment is that the Peninsula is dominated by vegetation from rural, agricultural, woodland and marshland sources which are likely to contain a higher amount of perylene compared to the anthropogenic input seen in the Delaware study area.

Further evidence for identifying urban and rural PAH sources, is demonstrated in the use of isomeric ratio cross plots (Figure 4) which were constructed based on the relative concentrations of isomeric pairs of PAHs whose ratios have been identified as diagnostic of PAH origin (Tobiszewski and Namiesnik, 2012; Yunker et al., 2002). The resulting three cross plots revealed that petrogenic inputs of PAHs did not predominate from the Delmarva, but in contrast in Delaware sediment, a distinct petroleum / petroleum combustion contribution was observed. The cross-plots from the Delmarva saltmarsh sediments strongly suggested $\mathrm{PAH}$ sources from grass-wood-coal combustion which would be expected from such a rural setting, very similar isomeric ratios has also be observed in the salt marshes of Barnegat Bay - Little Egg Harbour Estuary (Vane et al., 2008).

The only point that plot outside the purely combustion zones of the cross plots for the Delaware was from Floodgate (site 15), this was attributed to an unknown point source of triphenylene contamination; triphenylene co-elutes with chrysene during GC analysis and has a very similar mass spectrum to that of chrysene. 
Polychlorinated biphenyls (PCBs) are used e.g. as dielectric and coolant fluids in electrical equipment and in heat transfer fluids. PCBs are environmentally toxic and have possible carcinogenic properties. Consequently their industrial use and production was banned by the United States Congress in 1979 and by the Stockholm Convention on Persistent Organic Pollutants in 2001. Their environmental distribution and attenuation have been extensively documented (Johnson et al., 2006).

The concentrations of individual congeners (ICES 7 group) and total PCBs as well as summed tri-, tetra-, penta-, hexa-, hepta-chlorinated congeners are presented in Table 3. In this study the di-, octa-, nona-, and deca-PCBs were not determined and this has to be considered when comparing $\angle \mathrm{PCB}$ (tri-hepta) concentrations with other reported values where the total PCBs are calculated from the sum of a wider congener range.

PCB concentrations in the Delaware are significantly higher compared to the Delmarva. The mean concentration of $\Sigma P C B$ (ICES 7) in the Delaware $12.3 \mu \mathrm{g} / \mathrm{kg}$ (median $4.8 \mu \mathrm{g} / \mathrm{kg}$ ), whereas, in the Delmarva it was $0.8 \mu \mathrm{g} / \mathrm{kg}$ (median $0.7 \mu \mathrm{g} / \mathrm{kg}$ ). The sites presenting minimum and maximum PCB concentrations are identical to those listed for PAH concentrations, demonstrating the concomitant POPs loading at each of the sites.

The sediment quality guidelines (SQGs) for total PCBs for the ERM limit is 180 $\mu \mathrm{g} / \mathrm{kg}$ (Long et al., 1995) and the PEC limit is $676 \mu \mathrm{g} / \mathrm{kg}$ (MacDonald et al., 2000) for marine and estuarine ecosystems. This indicates that the PCBs may not be having adverse effect on aquatic organisms in both study areas. In the current study, the $\Sigma \mathrm{PCB}$ (tri-hepta) concentrations were indicative of background for both the Delaware and Delmarva (Table 3).

The $\Sigma P C B($ tri-hepta) concentrations of the Delmarva are significantly lower compared to that from a study of salt marsh surface sediments of Barnegat Bay-Little Egg Harbor Estuary, New Jersey, where it ranged from 4 to $50 \mu \mathrm{g} / \mathrm{kg}$ with a mean of $21 \mu \mathrm{g} / \mathrm{kg}$ (Vane et al., 2008). Higher values have been reported in surface sediments taken from the mudflats of the Mullica River, New Jersey, that has been relatively unaffected by industrial and urban influences (lannuzzi et al., 2005) where total PCB concentrations were $25-46 \mu \mathrm{g} / \mathrm{kg}$ (mean of $36 \mu \mathrm{g} / \mathrm{kg}$ ). This can be explained by the sorption of PCBs to clay and or natural organic matter (Fox et al., 2001; Scrimshaw and Lester, 2001). Generally as \%TOC of sediments increase so does its capacity for PCB sorption. In the Delmarva the mean TOC was 2.32\% (Table 1), whereas in Barnegat Bay and in the Mullica River the mean TOC were approximately twice as high at $4.91 \%$ and $4.34 \%$ respectively. The low PCB concentrations reported in this study (Table 3) supports the notion that the sediments of the Delmarva are not receiving significant inputs of PCB pollution.

In the current study, the $\mathrm{PPCB}$ (tri-hepta) mean concentration in the Delaware was $61.1 \mu \mathrm{g} / \mathrm{kg}$ and significantly higher than the Delmarva (Table 3 ), again this points to the close proximity of heavy industry in the vicinity of the Delaware which is a possible source. In a similar study of the Delaware River Estuary by other workers (Cavallo and Fikslin, 2011), the majority of sediments (also collected in 2008) were found to contain $\sim 0.4-150 \mu \mathrm{g} / \mathrm{kg}$ total PCBs (mean $\sim 10 \mu \mathrm{g} / \mathrm{kg}, \mathrm{n}=51$ ), although not directly comparable to our study (fewer homologues used), the values of Cavallo and Fikslin (2011) are broadly consistent with our study.

The PCB homologue distributions are presented (Figure 5). They are generally centred at the tetra-, penta- and hexa-chlorinated congeners. Although homologue 
distributions encountered here may be from industrial formulation Aroclor 1254 (the most widely sold mixture in the USA) the proportions of tri- and hepta-chlorinated were higher than would be expected if this was the sole source. The most plausible explanation being that factors such as dechlorination, volatilization and partitioning from air to water to sediment have probably also modified the congener profiles and homologue distributions to such an extent that source apportionment is beyond the scope of this study. The Delaware River Estuary has a history of being impacted by PCB contamination (Fikslin and Greene, 1998). In 2003 a total maximum daily load (TMDL) for PCBs was issued by the Delaware River Basin Commission via the Clean Water Act to minimize PCB pollution. To assist with this management strategy, PCB congener data have been used to help establish pollution source apportionment (Du et al., 2008; Praipipat et al., 2013). These studies have demonstrated the importance of non-Aroclor PCB sources. For example, a PCB 'fingerprint' was observed in the vicinity of a plant near Wilmington which produces high molecular weight (nona/deca-chlorinated) congeners as a by-product in the manufacture of $\mathrm{TiCl}_{4}$ used in pigment production. Another significant non-Aroclor signal is from the atmospheric deposition of PCB11 (a dichlorinated PCB) used in the production of diarylide yellow pigment (Praipipat et al., 2013). However in the current study the di-, octa-, nona-, and deca-PCBs were not determined and consequently we are not able to detect a non-Aroclor congener signal which would concomitantly increase the Delaware total PCB concentrations. 
To Conclude: The concentration of PCBs, TPH and total Hg in the majority of surface sediments were considered mainly to be within regional (i.e. industrialized and rural) background levels in both of the study areas. Concentrations are elevated throughout the Delaware River Estuary study area compared to the Delmarva Peninsula. Applying suitable SQG (PEC) values to the Delaware Estuary sediments, the PAH concentrations are unlikely for have adverse effects aquatic life and ecosystems using these habitats. Spatial trends showing elevated concentrations in the vicinity of heavy industry for $\mathrm{Hg}$ and TPH were only observed in the Delaware but none were seen in the rural Delmarva study area. The presence of multiple heavy industry and historic discharge into the Delaware indicates multiple diffuse sources of $\mathrm{Hg}, \mathrm{TPH}, \mathrm{PAHs}$, and PCBs. The combined use of $\mathrm{PAH}$ isomeric ratios, \% perylene, and saturate aromatic ratios demonstrate that the majority of hydrocarbons in the Delaware are from anthropogenic / pyrolytic / petroleum sources whereas in the Delmarva they are mainly of biogenic origin.

\section{Acknowledgements}

C. H. Vane and co-authors indebted to Earthwatch Institute Students who assisted with sample collection. HPLC analysis was conducted by Dr. lan Harrison. This paper is published by permission of the Executive Director, British Geological Survey. 


\section{References}

Alexander, C.R., Lee, R.F., Burton, D.T., Hall, L.W., 2005. An integrated case study for evaluating the impacts of an oil refinery effluent on aquatic biota in the Delaware River: Sediment core studies. Human and Ecological Risk Assessment, 11(4): 861-877.

Armstrong, T.N., Iannuzzi, T.J., Thelen, J.B., Ludwig, D.F., Firstenberg, C.E., 2005. Characterization of chemical contamination in shallow-water estuarine habitats of an industrialized river. Part II. Metals. Soil \& Sediment Contamination, 14(1): 35-52.

Barrett, K.R., McBrien, M.A., 2007. Chemical and biological assessment of an urban, estuarine marsh in northeastern New Jersey, USA. Environmental Monitoring and Assessment, 124(1-3): 63-88.

Beriro, D.J., Vane, C.H., Cave, M.R., Nathanail, C.P., 2014. Effects of drying and comminution type on the quantification of Polycyclic Aromatic Hydrocarbons (PAH) in a homogenised gasworks soil and the implications for human health risk assessment. Chemosphere, 111: 396-404.

Bigham, G.N., Henry, B., B., B., 2006. Mercury. In: Morrison, R.D., Murphy, B.L. (Eds.), Environmental Forensics. Elsevier Academic Press, Burlington, MA, USA, pp. 1-18.

Boehm, P.D., 2006. Polycyclic Aromatic Hydrocarbons. In: Morrison, R.D., Murphy, B.L. (Eds.), Environmental Forensics. Elsevier Academic Press, Burlington, MA, USA, pp. 313-338.

Boening, D.W., 2000. Ecological effects, transport, and fate of mercury: a general review. Chemosphere, 40(12): 1335-1351.

Cavallo, G.J., Fikslin, T.J., 2011. Evaluation of PCBs and Dioxin / Furans (DxFs) Concentrations in Sediment from the Delaware Estuary, Delaware Estuary Science and Environmental Summit. Delaware River Basin Commission.

Church, T.M. et al., 2006. Marsh sediments as records of sedimentation, eutrophication and metal pollution in the urban Delaware Estuary. Marine Chemistry, 102(1-2): 72-95.

Conde, F.J., Ayala, J.H., Afonso, A.M., Gonzalez, V., 2005. Emissions of polycyclic aromatic hydrocarbons from combustion of agricultural and sylvicultural debris. Atmospheric Environment, 39(35): 6654-6663.

Connolly, J.P., Pedersen, C.J., 1988. A thermodynamic-based evaluation of organic-chemical accumulation in aquatic organisms. Environmental Science \& Technology, 22(1): 99-103.

Culliton, T.J. et al., 1990. Fifty years of population change along the nation's coast, 1960-2010, Strategic Environmental Assessments Division, OCRA/NOS/NOAA, Silver Springs, MD.

Du, S., Belton, T.J., Rodenburg, L.A., 2008. Source apportionment of polychlorinated biphenyls in the tidal Delaware River. Environmental Science \& Technology, 42(11): 4044-4051.

Fikslin, T.J., Greene, R.W., 1998. Study of the loadings of polychlorinated biphenyls from tributaries and point sources discharging to the tidal Delaware River., Estuary Toxics Management Program, Delaware River Basin Commission, West Trenton, New Jersey.

Fox, W.M., Connor, L., Copplestone, D., Johnson, M.S., Leah, R.T., 2001. The organochlorine contamination history of the Mersey estuary, UK, revealed by analysis of sediment cores from salt marshes. Marine Environmental Research, 51(3): 213-227.

Gonzalez-Perez, J.A., Gonzalez-Vila, F.J., Almendros, G., Knicker, H., 2004. The effect of fire on soil organic matter - a review. Environment International, 30(6): 855-870.

Haitzer, M., Aiken, G.R., Ryan, J.N., 2003. Binding of mercury(II) to aquatic humic substances: Influence of pH and source of humic substances. Environmental Science \& Technology, 37(11): 2436-2441.

Hall, L.W., Burton, D.T., 2005. An integrated case study for evaluating the impacts of an oil refinery effluent on aquatic biota in the Delaware River: Introduction, study approach, and objectives. Human and Ecological Risk Assessment, 11(4): 647-656.

Huntley, S.L., Bonnevie, N.L., Wenning, R.J., 1995. Polycyclic aromatic hydrocarbon and petroleum hydrocarbon contamination in sediment from the Newark Bay Estuary, New-Jersey. Archives of Environmental Contamination and Toxicology, 28(1): 93-107.

Iannuzzi, T.J., Armstrong, T.N., Thelen, J.B., Ludwig, D.F., Firstenberg, C.E., 2005. Characterization of chemical contamination in shallow-water estuarine habitats of an industrialized river. Part 1: Organic compounds. Soil \& Sediment Contamination, 14(1): 13-33.

Iannuzzi, T.J., Huntley, S.L., Bonnevie, N.L., Finley, B.L., Wenning, R.J., 1995. Distribution and possible sources of polychlorinated-biphenyls in dated sediments from the Newark Bay Estuary, New-Jersey. Archives of Environmental Contamination and Toxicology, 28(1): 108-117.

Johnson, G.W., Quenson, J.F.I., Chiarenzelli, J.R., Hamilton, M.C., 2006. Polychlorinated Biphenyls. In: Morrison, R.D., Murphy, B.L. (Eds.), Environmental Forensics. Elsevier Academic Press, Burlington, MA, USA, pp. 187-226.

Kakareka, S.V., Kukharchyk, T.I., 2003. PAH emission from the open burning of agricultural debris. Science of the Total Environment, 308(1-3): 257-261. 
Kannan, K., Falandysz, J., 1998. Speciation and concentrations of mercury in certain coastal marine sediments. Water Air and Soil Pollution, 103(1-4): 129-136.

Kastler, J.A., Wiberg, P.L., 1996. Sedimentation and boundary changes of Virginia salt marshes. Estuarine Coastal and Shelf Science, 42(6): 683-700.

Kelly, B.C., Ikonomou, M.G., Blair, J.D., Morin, A.E., Gobas, F.A.P.C., 2007. Food web-specific biomagnification of persistent organic pollutants. Science, 317(5835): 236-239.

Long, E.R., Macdonald, D.D., Smith, S.L., Calder, F.D., 1995. Incidence of adverse biological effects within ranges of chemical concentrations in marine and estuarine sediments. Environmental Management, 19(1): 81-97.

Luo, X.-J. et al., 2008. Distribution, source apportionment, and transport of PAHs in sediments from the Pearl River Delta and the northern South China Sea. Archives of Environmental Contamination and Toxicology, 55(1): 11-20.

MacDonald, D.D., Ingersoll, C.G., Berger, T.A., 2000. Development and evaluation of consensus-based sediment quality guidelines for freshwater ecosystems. Archives of Environmental Contamination and Toxicology, 39(1): 20-31.

McLusky, D.S., Elliott, M., 2004. The Estuarine Ecosystem - Ecology, Threats, and Management. Oxford University Press.

Mrozek, E., Queen, W.H., Hobbs, L.L., 1983. Effects of polychlorinated-biphenyls on growth of Spartina-Alterniflora Loisel. Environmental and Experimental Botany, 23(4): 285-292.

Pohlman, J.W. et al., 2002. Transport, deposition and biodegradation of particle bound polycyclic aromatic hydrocarbons in a tidal basin of an industrial watershed. Environmental Monitoring and Assessment, 75(2): 155-167.

Praipipat, P., Rodenburg, L.A., Cavallo, G.J., 2013. Source Apportionment of Polychlorinated Biphenyls in the Sediments of the Delaware River. Environmental Science \& Technology, 47(9): 4277-4283.

Sanger, D.M., Holland, A.F., Hernandez, D.L., 2004. Evaluation of the impacts of dock structures and land use on tidal creek ecosystems in South Carolina estuarine environments. Environmental Management, 33(3): 385-400.

Sanger, D.M., Holland, A.F., Scott, G.I., 1999a. Tidal creek and salt marsh sediments in South Carolina coastal estuaries: I. Distribution of trace metals. Archives of Environmental Contamination and Toxicology, 37(4): 445-457.

Sanger, D.M., Holland, A.F., Scott, G.I., 1999b. Tidal creek and salt marsh sediments in South Carolina coastal estuaries: II. Distribution of organic contaminants. Archives of Environmental Contamination and Toxicology, 37(4): 458-471.

Scrimshaw, M.D., Lester, J.N., 2001. Multivariate analysis of UK salt marsh sediment contaminant data with reference to the significance of PCB contamination. Environmental Science \& Technology, 35(13): 2676-2681.

Shi, J.-b. et al., 2007. Spatial and temporal variations of mercury in sediments from Victoria Harbour, Hong Kong. Marine Pollution Bulletin, 54(4): 480-485.

Silliman, J.E., Meyers, P.A., Eadie, B.J., 1998. Perylene: an indicator of alteration processes or precursor materials? Organic Geochemistry, 29(5-7): 1737-1744.

Sutton, C.C., O'Herron, J.C., Zappalorti, R.T., 1996. The Scientific Characterization of the Delaware Estuary, Delaware River Basin Commission, West Trenton, NJ, USA.

Tarr, J.A., McCurley, J., 1984. Pollution Trends in Five Estuaries, 1880-1980. The Potomac, the Delaware, the Hudson-Raritan, the Connecticut, the Narrangansett., Carnegie-Melon University, Pittsburgh, PA, USA.

Tobiszewski, M., Namiesnik, J., 2012. PAH diagnostic ratios for the identification of pollution emission sources. Environmental Pollution, 162: 110-119.

Uhler, A.D., Emsbo-Mattingly, S., Liu, B., Hall, L.W., Burton, D.T., 2005. An integrated case study for evaluating the impacts of an oil refinery effluent on aquatic biota in the Delaware River: Advanced chemical fingerprinting of PAHs. Human and Ecological Risk Assessment, 11(4): 771-836.

Vane, C.H., Beriro, D.J., Turner, G.H., 2015. Rise and fall of mercury (Hg) pollution in sediment cores of the Thames Estuary, London, UK. Earth and Environmental Science Transactions of the Royal Society of Edinburgh, 105: 285-296.

Vane, C.H., Harrison, I., Kim, A.W., 2007. Assessment of polyaromatic hydrocarbons (PAHs) and polychlorinated biphenyls (PCBs) in surface sediments of the Inner Clyde Estuary, UK. Marine Pollution Bulletin, 54(8): 1301-1306.

Vane, C.H. et al., 2008. Status of organic pollutants in surface sediments of Barnegat Bay-Little Egg Harbor Estuary, New Jersey, USA. Marine Pollution Bulletin, 56(10): 1802-1808.

Vane, C.H., Jones, D.G., Lister, T.R., 2009. Mercury contamination in surface sediments and sediment cores of the Mersey Estuary, UK. Marine Pollution Bulletin, 58(6): 940-946.

Vane, C.H. et al., 2013. Sedimentary transport and fate of polycyclic aromatic hydrocarbons (PAH) from managed burning of moorland vegetation on a blanket peat, South Yorkshire, UK. Science of the Total Environment, 
449: 81-94.

Venkatesan, M.I., 1988. Occurrence and possible sources of perylene in marine-sediments - a review. Marine Chemistry, 25(1): 1-27.

Volkman, J.K., Holdsworth, D.G., Neill, G.P., Bavor, H.J., 1992. Identification of natural, anthropogenic and petroleum-hydrocarbons in aquatic sediments. Science of the Total Environment, 112(2-3): 203-219.

Volkman, J.K., Nichols, P.D., 1991. Applications of thin layer chromatography-flame ionization detection to the analysis of lipids and pollutants in marine and environmental samples. Journal of Planar Chromatography - Modern TLC, 4(1): 19-26.

Wall, V.D. et al., 2001. The effect of mercury and PCBs on organisms from lower trophic levels of a Georgia salt marsh. Archives of Environmental Contamination and Toxicology, 40(1): 10-17.

Watts, A.W., Ballestero, T.P., Gardner, K.H., 2006. Uptake of polycyclic aromatic hydrocarbons (PAHs) in salt marsh plants Spartina alterniflora grown in contaminated sediments. Chemosphere, 62(8): 1253-1260.

White, H.K., Xu, L., Lima, A.L.C., Eglinton, T.I., Reddy, C.M., 2005. Abundance, composition, and vertical transport of PAHs in marsh sediments. Environmental Science \& Technology, 39(21): 8273-8280.

Wilcke, W., 2007. Global patterns of polycyclic aromatic hydrocarbons (PAHs) in soil. Geoderma, 141(3-4): 157-166.

Yunker, M.B. et al., 2002. PAHs in the Fraser River basin: a critical appraisal of PAH ratios as indicators of PAH source and composition. Organic Geochemistry, 33(4): 489-515. 
Table 1. Total organic carbon (\% TOC), total $\mathrm{Hg}$ ( $\mathrm{mg} / \mathrm{kg}$ dry wt) and total (extractable, non-volatile) petroleum hydrocarbons (TPH) in sediments from the Delmarva (sites 1-12) and Delaware River (sites 13-21) study areas. Quality control reference materials were MESS-3 (a marine sediment certified reference material from the National Research Council Canada) and in-house quality control sediments. Marine / estuarine sediment quality values (SQVs) are presented where PEC is the probable effects concentration, ERM is the effects range median, TEC is the threshold effect concentration and $\mathrm{ERL}$ is the effects range low.

\begin{tabular}{|c|c|c|c|c|c|c|c|c|c|c|}
\hline I.D. & Site Name & Longitude (decimal) & Latitude (decimal) & TOC (\%) & $\mathrm{Hg}(\mathrm{mg} / \mathrm{kg})$ & TPH (mg/kg) & $\begin{array}{c}\text { Aromatics } \\
(\mathrm{mg} / \mathrm{kg})\end{array}$ & $\begin{array}{l}\text { Saturates } \\
(\mathrm{mg} / \mathrm{kg})\end{array}$ & $\begin{array}{l}\text { Aromatics } \\
(\%)\end{array}$ & $\begin{array}{c}\text { Saturates } \\
(\%)\end{array}$ \\
\hline 1 & Chincoteague Road & 37.94076 & 75.44227 & 3.41 & 0.09 & 87 & 11 & 77 & $13 \%$ & $89 \%$ \\
\hline 2 & Sanford & 37.93858 & 75.67121 & 1.58 & 0.06 & 141 & 42 & 98 & $30 \%$ & $70 \%$ \\
\hline 3 & Louisville & 37.65347 & 75.65574 & 3.95 & 0.08 & 77 & 20 & 56 & $26 \%$ & $73 \%$ \\
\hline 4 & Wachapreague & 37.60106 & 75.69001 & 2.95 & 0.10 & 79 & 21 & 59 & $27 \%$ & $75 \%$ \\
\hline 5 & Bradford Neck Road & 37.53311 & 75.74141 & 0.15 & $<0.02$ & $<34$ & $<3$ & $<31$ & & \\
\hline 6 & Brownsville & 37.45812 & 75.81896 & 0.73 & 0.02 & 37 & $<3$ & 37 & & \\
\hline 7 & Boxtree Farm & 37.39568 & 75.86998 & 1.53 & 0.07 & 51 & $<3$ & 51 & & \\
\hline 8 & Indian Village Road & 37.35071 & 75.90047 & 2.62 & 0.09 & 74 & 19 & 55 & $26 \%$ & $74 \%$ \\
\hline 9 & Oyster Bay & 37.28773 & 75.91784 & 0.49 & 0.03 & $<34$ & 8 & $<31$ & & \\
\hline 10 & Braxton Farm Drive & 37.20486 & 75.93775 & 4.39 & 0.07 & 81 & 23 & 58 & $28 \%$ & $72 \%$ \\
\hline 11 & Magothy Bay & 37.14027 & 75.94189 & 3.64 & 0.05 & 69 & 20 & 49 & $29 \%$ & $71 \%$ \\
\hline 12 & Southern Tip & 37.12908 & 75.95486 & 2.36 & 0.06 & 159 & 72 & 87 & $45 \%$ & $55 \%$ \\
\hline Delmarva & Mean & & & 2.32 & 0.07 & 86 & 26 & 63 & $28 \%$ & $72 \%$ \\
\hline Delmarva & Median & & & 2.49 & 0.07 & 78 & 20 & 57 & $27 \%$ & $72 \%$ \\
\hline 13 & Trenton North & 40.23822 & 74.80900 & 3.95 & 0.07 & 195 & 37 & 158 & $19 \%$ & $81 \%$ \\
\hline 14 & Burlington Island & 40.09132 & 74.09132 & 2.08 & 0.04 & 240 & 75 & 164 & $31 \%$ & $68 \%$ \\
\hline 15 & Floodgate & 39.83095 & 75.33162 & 5.30 & 0.04 & 242 & 107 & 135 & $44 \%$ & $56 \%$ \\
\hline 16 & Fox Point & 39.75765 & 75.48870 & 0.33 & 0.06 & 212 & 66 & 146 & $31 \%$ & $69 \%$ \\
\hline 17 & Carney Point & 39.71485 & 75.47670 & 6.23 & 0.25 & 543 & 307 & 236 & $57 \%$ & $43 \%$ \\
\hline 18 & Deeves Beach & 39.65288 & 75.58392 & 9.05 & 0.28 & 616 & 233 & 383 & $38 \%$ & $62 \%$ \\
\hline 19 & Reedy Point & 39.55940 & 75.56603 & 3.23 & 0.18 & 201 & 104 & 97 & $52 \%$ & $48 \%$ \\
\hline 20 & Elfsborg & 39.54513 & 75.52980 & 0.05 & $<0.02$ & 38 & 38 & $<31$ & & \\
\hline 21 & Augustine Beach & 39.50605 & 75.57912 & 1.94 & 0.09 & 151 & 74 & 77 & $49 \%$ & $51 \%$ \\
\hline Delaware & Mean & & & 3.57 & 0.13 & 271 & 116 & 175 & $40 \%$ & $60 \%$ \\
\hline \multirow[t]{5}{*}{ Delaware } & Median & & & 3.23 & 0.08 & 212 & 75 & 152 & $41 \%$ & $59 \%$ \\
\hline & QC name & & & in-house & MESS-3 & in-house & in-house & in-house & & \\
\hline & Assigned Value & & & 7.53 & 0.091 & 2934 & 761 & 2172 & & \\
\hline & Uncertainty & & & \pm 0.15 & \pm 0.01 & \pm 587 & \pm 152 & \pm 434 & & \\
\hline & Permissible max. & & & 7.91 & 0.10 & 3668 & 951 & 2715 & & \\
\hline
\end{tabular}


PEC (MacDonald et al., 2000)

ERM (Long et al. 1995)

0.71

TEC (MacDonald et al., 2000)

ERL (Long et al. 1995)

0.15 
Table 2. PAH concentrations ( $\mu \mathrm{g} / \mathrm{kg}$ dry wt) in the Delmarva (sites 1-12) and Delaware River (sites 13-21) study areas compared to quality control quality control reference materials NRCHS 5 (a marine sediment certified reference material from the National Research Council Canada). Marine / estuarine sediment quality values (SQVs) are presented where PEC is the probable effects concentration, ERM is the effects range median, TEC is the threshold effect concentration, ERL is the effects range low and NOAA is the National Oceanic and Atmospheric Administration. Standard deviation is given in the parentheses, where $\mathrm{n}$ are the number of analyses, n.d. $=$ not determined. $\angle \mathrm{LoQ}=$ less than limit of quantification. $\dagger$ value for total PAHs. Naph: naphthalene, 1-MN: 1-methylnaphthalene, 2-MN: 2-methynaphthalene, Ace: acenaphthene, Fluor: fluorene, Phen: phenanthrene, Anth: anthracene, Fanth: fluoranthene, Pyr: pyrene, B[a]A: benzo[a]anthracene, Chrys: chrysene, TPh: triphenylene, B[b]F: benzo[b]fluoranthene, Pery: perylene, B[A]F: benzo[A]fluoranthene, B[a]P: benzo[a]pyrene, DBA: dibenz[a,h]anthracene, B[ghi]P: benzo[g,h,i]perylene, IP: indeno[1,2,3-c,d]pyrene.

\begin{tabular}{|c|c|c|c|c|c|c|c|c|c|c|c|c|c|c|c|c|c|c|c|c|c|}
\hline Site No. & Site Name & Naph & 1-MN & 2-MN & Ace & Fluor & Phen & Anth & Fanth & Pyr & $\mathrm{B}[\mathrm{a}] \mathrm{A}$ & Chrys + TPh & $\mathrm{B}[\mathrm{b}] \mathrm{F}$ & Pery & $\mathrm{B}[\mathrm{k}] \mathrm{F}$ & $\mathrm{B}[\mathrm{a}] \mathrm{P}$ & DBA & $\mathrm{B}[$ ghi]P & IP & $\sum$ PAH 18 & $\%$ pery \\
\hline 1 & Chincoteague Road & 13 & 3 & 5 & 1 & 2 & 11 & 4 & 22 & 16 & 7 & 7 & 2 & 2 & 0 & 0 & $<\mathrm{LoQ}$ & $<\mathrm{LoQ}$ & 0 & 96 & $2 \%$ \\
\hline 2 & Sanford & 5 & 4 & 3 & 5 & 8 & 139 & 22 & 288 & 263 & 142 & 149 & 158 & 49 & 87 & 165 & 18 & 112 & 97 & 1714 & $3 \%$ \\
\hline 3 & Louisville & 6 & 1 & 4 & 0 & 3 & 13 & 4 & 28 & 14 & 9 & 10 & 16 & 50 & 8 & 9 & 3 & 10 & 9 & 197 & $26 \%$ \\
\hline 4 & Wachapreague & 8 & 3 & 7 & 1 & 4 & 16 & 7 & 44 & 26 & 18 & 17 & 30 & 59 & 18 & 21 & 3 & 17 & 17 & 317 & $19 \%$ \\
\hline 5 & Bradford Neck Road & 0 & $<$ LoQ & $<L \circ Q$ & $<L \circ Q$ & $<$ LoQ & $<$ LoQ & $<$ LoQ & $<$ LoQ & $<$ LoQ & $<\mathrm{LoQ}$ & 0 & 1 & 1 & $<$ LoQ & 0 & $<$ LoQ & 1 & 0 & 5 & $25 \%$ \\
\hline 6 & Brownsville & $<$ LoQ & $<L \circ Q$ & $<L \circ Q$ & $<$ LoQ & 0 & 2 & 1 & 6 & 3 & 3 & 3 & 4 & 9 & 4 & 3 & $<L o Q$ & 3 & 2 & 42 & $21 \%$ \\
\hline 7 & Boxtree Farm & 4 & 2 & 3 & $<L \circ Q$ & 2 & 8 & 3 & 22 & 11 & 7 & 8 & 15 & 32 & 7 & 7 & $<L \circ Q$ & 6 & 6 & 143 & $23 \%$ \\
\hline 8 & Indian Village Road & 11 & 3 & 7 & 1 & 3 & 14 & 4 & 28 & 12 & 10 & 9 & 16 & 43 & 9 & 10 & 1 & 14 & 7 & 200 & $21 \%$ \\
\hline 9 & Oyster Bay & 2 & $<$ LoQ & 0 & $<$ LoQ & 0 & 2 & 1 & 10 & 9 & 8 & 10 & 11 & 9 & 5 & 8 & $<$ LoQ & 11 & 5 & 91 & $10 \%$ \\
\hline 10 & Braxton Farm Drive & 5 & 2 & 3 & 1 & 2 & 17 & 7 & 132 & 111 & 66 & 86 & 108 & 41 & 55 & 56 & 10 & 36 & 49 & 789 & $5 \%$ \\
\hline 11 & Magothy Bay & 5 & 1 & 1 & 0 & 1 & 8 & 1 & 12 & 7 & 5 & 6 & 11 & 13 & 6 & 3 & $<$ LoQ & 7 & 3 & 89 & $15 \%$ \\
\hline 12 & Southern Tip & 35 & 40 & 51 & 3 & 13 & 123 & 26 & 250 & 179 & 112 & 110 & 255 & 95 & 126 & 180 & 45 & 277 & 219 & 2139 & $4 \%$ \\
\hline Delmarva & Mean & 9 & 7 & 8 & 2 & 4 & 32 & 7 & 77 & 59 & 35 & 34 & 52 & 34 & 30 & 39 & 13 & 45 & 34 & 485 & $14 \%$ \\
\hline Delmarva & Median & 5 & 3 & 3 & 1 & 2 & 13 & 4 & 28 & 14 & 9 & 9 & 15 & 37 & 8 & 8 & 7 & 11 & 7 & 170 & $17 \%$ \\
\hline 13 & Trenton North & 163 & 57 & 61 & 63 & 267 & 578 & 134 & 912 & 1223 & 884 & 443 & 539 & 205 & 225 & 723 & 171 & 736 & 522 & 7907 & $3 \%$ \\
\hline 14 & Burlington Island & 124 & 28 & 41 & 40 & 231 & 627 & 185 & 698 & 975 & 574 & 325 & 349 & 126 & 188 & 494 & 67 & 374 & 296 & 5742 & $2 \%$ \\
\hline 15 & Floodgate & 122 & 39 & 53 & 86 & 272 & 428 & 83 & 440 & 542 & 307 & 3910 & 139 & 297 & 68 & 222 & n.d. & 191 & 177 & 7374 & $4 \%$ \\
\hline 16 & Fox Point & 113 & 26 & 56 & 36 & 89 & 330 & 65 & 423 & 483 & 389 & 297 & 317 & 89 & 160 & 263 & 39 & 333 & 243 & 3749 & $2 \%$ \\
\hline 17 & Carney Point & 175 & 74 & 89 & 156 & 305 & 606 & 242 & 792 & 1152 & 863 & 565 & 425 & 274 & 213 & 672 & 78 & 429 & 386 & 7495 & $4 \%$ \\
\hline 18 & Deeves Beach & 173 & 111 & 169 & 321 & 1532 & 1942 & 728 & 2258 & 3020 & 2945 & 1328 & 1161 & 612 & 702 & 2100 & 289 & 1489 & 1443 & 22324 & $3 \%$ \\
\hline 19 & Reedy Point & 146 & 48 & 80 & 43 & 146 & 202 & 64 & 219 & 350 & 242 & 153 & 174 & 362 & 76 & 257 & 31 & 238 & 199 & 3030 & $12 \%$ \\
\hline 20 & Elfsborg & n.d. & n.d. & n.d. & n.d. & n.d. & n.d. & 29 & 227 & 286 & 203 & 211 & 328 & 161 & 118 & 430 & 41 & 188 & 133 & n.d. & n.d. \\
\hline 21 & Augustine Beach & 119 & 30 & 53 & 14 & 191 & 280 & 75 & 280 & 365 & 228 & 149 & 133 & 197 & 59 & 256 & n.d. & 163 & 137 & 2729 & $7 \%$ \\
\hline Delaware & Mean & 142 & 52 & 75 & 95 & 379 & 624 & 178 & 694 & 933 & 737 & 820 & 396 & 258 & 201 & 602 & 102 & 460 & 393 & 7544 & $5 \%$ \\
\hline
\end{tabular}




\begin{tabular}{|c|c|c|c|c|c|c|c|c|c|c|c|c|c|c|c|c|c|c|c|c|c|}
\hline Delaware & Median & 135 & 43 & 58 & 53 & 249 & 503 & 83 & 440 & 542 & 389 & 325 & 328 & 205 & 160 & 430 & 67 & 333 & 243 & 6558 & $3 \%$ \\
\hline \multirow[t]{2}{*}{ NRCHS 5} & $\begin{array}{c}\text { Certificate } \\
\text { Values } \\
\text { Value obtained } \\
(n=27)\end{array}$ & $\begin{array}{c}250 \\
( \pm 70) \\
243 \\
( \pm 76)\end{array}$ & $\begin{array}{c}\text { not listed } \\
86 \\
( \pm 24)\end{array}$ & $\begin{array}{c}\text { not listed } \\
109 \\
( \pm 33)\end{array}$ & $\begin{array}{c}230 \\
( \pm 100) \\
246 \\
( \pm 131)\end{array}$ & $\begin{array}{c}400 \\
( \pm 100) \\
402 \\
( \pm 99)\end{array}$ & $\begin{array}{c}5200 \\
( \pm 1000) \\
5235 \\
( \pm 356)\end{array}$ & $\begin{array}{c}380 \\
( \pm 150) \\
366 \\
( \pm 63)\end{array}$ & $\begin{array}{c}8400 \\
( \pm 2600) \\
8322 \\
( \pm 924)\end{array}$ & $\begin{array}{c}5800 \\
( \pm 1800) \\
5792 \\
( \pm 347)\end{array}$ & $\begin{array}{c}2900 \\
( \pm 1200) \\
2857 \\
( \pm 257)\end{array}$ & $\begin{array}{c}2800 \\
( \pm 900) \\
2814 \\
( \pm 321)\end{array}$ & $\begin{array}{c}2000 \\
( \pm 1000) \\
2012 \\
( \pm 144)\end{array}$ & $\begin{array}{c}\text { Not } \\
\text { listed } \\
466 \\
( \pm 62)\end{array}$ & $\begin{array}{c}1000 \\
( \pm 400) \\
967 \\
( \pm 72)\end{array}$ & $\begin{array}{c}1700 \\
( \pm 800) \\
1696 \\
( \pm 165)\end{array}$ & $\begin{array}{c}200 \\
( \pm 100) \\
196 \\
( \pm 31)\end{array}$ & $\begin{array}{l}1300 \\
( \pm 300) \\
1292 \\
( \pm 111)\end{array}$ & $\begin{array}{l}1300 \\
( \pm 700) \\
1245 \\
( \pm 143)\end{array}$ & & \\
\hline & LoQ & 7 & 6 & 5 & 4 & 50 & 5 & 5 & 4 & 4 & 1 & 2 & 2 & 4 & 2 & 10 & 4 & 7 & 4 & & \\
\hline \multicolumn{2}{|c|}{ PEC (MacDonald et al., 2000) } & 561 & & & & 536 & 1170 & 845 & 2230 & 1520 & 1050 & 1290 & & & & 1450 & & & & $22800^{\dagger}$ & \\
\hline NOAA; ERN & (Long et al. 1995) & 2100 & & 670 & 500 & 540 & 1500 & 1100 & 5100 & 2600 & 1600 & 2800 & & & & 1600 & 260 & & & $44792^{\dagger}$ & \\
\hline \multicolumn{2}{|c|}{ TEC (MacDonald et al., 2000) } & 176 & & & & 77 & 204 & 57.2 & 423 & 195 & 108 & 166 & & & & 150 & 33 & & & $1610^{\dagger}$ & \\
\hline \multicolumn{2}{|c|}{ NOAA; ERL (Long et al. 1995) } & 160 & & 70 & 15 & 19 & 240 & 85.3 & 600 & 665 & 261 & 384 & & & & 430 & 63.4 & & & $4022^{\dagger}$ & \\
\hline
\end{tabular}


Table 3. Surface sediment PCB concentrations ( $\mu \mathrm{g} / \mathrm{kg}$ dry wt.) from the Delmarva Peninsula, Delaware River and quality control PCB concentrations for National Water Research Institute reference material EC-1 in harbor sediment and relevant marine / estuarine sediment quality values (SQVs). Standard deviation is given in the parentheses, where $\mathrm{n}$ are the number of analyses, n.d. $=$ not determined. $\angle$ LoQ $=$ less than limit of quantification. $a=$ possible interference at $\mathrm{m} / \mathrm{z} 258$ for tri-chlorinated PCBs observed in this sample.

\begin{tabular}{|c|c|c|c|c|c|c|c|c|c|c|c|c|c|c|c|}
\hline Site No. & Site Name & РСB 028 & PCB 052 & PCB 101 & РCB 118 & РCB 153 & РCB 138 & PCB 180 & $\sum$ PCB (ICES 7) & $3-\mathrm{Cl}$ & $4-\mathrm{Cl}$ & $5-\mathrm{Cl}$ & $6-\mathrm{Cl}$ & $7-\mathrm{Cl}$ & $\sum \mathrm{PCB}$ (tri-hepta) \\
\hline 1 & Chincoteague Road & 0.1 & 0.0 & 0.0 & 0.1 & 0.4 & 0.2 & 0.0 & 0.9 & 0.6 & 0.5 & 1.0 & 0.8 & 0.6 & 3.4 \\
\hline 2 & Sanford & 0.0 & 0.0 & 0.0 & 0.0 & 0.1 & 0.0 & 0.0 & 0.1 & 0.0 & 0.1 & 0.5 & 0.3 & 0.2 & 1.1 \\
\hline 3 & Louisville & 0.0 & 0.1 & 0.0 & 0.0 & 0.4 & 0.0 & 0.0 & 0.5 & 0.1 & 0.2 & 0.6 & 0.7 & 4.0 & 5.6 \\
\hline 4 & Wachapreague & 0.2 & 0.1 & 0.0 & 0.2 & 0.4 & 0.0 & 0.2 & 1.2 & 0.3 & 0.9 & 1.3 & 1.0 & 1.4 & 4.8 \\
\hline 5 & Bradford Neck Road & 0.0 & 0.0 & 0.0 & 0.0 & 0.0 & 0.0 & 0.0 & 0.0 & 0.0 & 0.0 & 0.4 & 0.1 & 0.1 & 0.6 \\
\hline 6 & Brownsville & 0.2 & 0.0 & 0.0 & 0.0 & 0.0 & 0.0 & 0.0 & 0.3 & $5.3^{\mathrm{a}}$ & 0.1 & 0.7 & 0.0 & 0.4 & 6.5 \\
\hline 7 & Boxtree Farm & 0.0 & 0.1 & 0.0 & 0.1 & 0.4 & 0.2 & 0.0 & 0.8 & 0.3 & 0.2 & 0.5 & 1.0 & 0.3 & 2.3 \\
\hline 8 & Indian Village Road & 0.1 & 0.1 & 0.1 & 0.1 & 0.1 & 0.1 & 0.0 & 0.6 & 0.2 & 0.6 & 0.6 & 0.6 & 0.7 & 2.7 \\
\hline 9 & Oyster Bay & 0.0 & 0.0 & 0.0 & 0.0 & 0.0 & 0.1 & 0.0 & 0.2 & 0.0 & 0.1 & 0.3 & 0.2 & 0.5 & 1.1 \\
\hline 10 & Braxton Farm Drive & 0.1 & 0.1 & 0.2 & 0.0 & 0.7 & 0.3 & 0.2 & 1.5 & 0.3 & 0.7 & 1.2 & 1.3 & 2.7 & 6.1 \\
\hline 11 & Magothy Bay & 0.1 & 0.1 & 0.2 & 0.1 & 0.4 & 0.2 & 0.1 & 1.2 & 0.2 & 0.4 & 0.6 & 1.2 & 2.0 & 4.4 \\
\hline 12 & Southern Tip & 0.0 & 0.1 & 0.3 & 0.2 & 0.9 & 0.4 & 0.0 & 2.0 & 0.0 & 0.0 & 1.2 & 1.8 & 0.9 & 4.0 \\
\hline Delmarva & Mean & 0.1 & 0.1 & 0.1 & 0.1 & 0.3 & 0.1 & 0.0 & 0.8 & 0.6 & 0.3 & 0.7 & 0.7 & 1.2 & 3.6 \\
\hline Delmarva & Median & 0.1 & 0.1 & 0.0 & 0.0 & 0.4 & 0.1 & 0.0 & 0.7 & 0.2 & 0.2 & 0.6 & 0.7 & 0.6 & 3.7 \\
\hline 13 & Trenton North & 0.4 & 0.5 & 1.0 & 0.5 & 0.5 & 0.0 & 0.0 & 2.8 & 11.8 & 4.0 & 18.2 & 18.0 & 7.2 & 59.2 \\
\hline 14 & Burlington Island & 0.4 & 0.3 & 3.0 & 1.7 & 9.3 & 5.4 & 12.1 & 32.2 & 6.8 & 2.2 & 24.3 & 47.6 & 29.6 & 110.6 \\
\hline 15 & Floodgate & 0.2 & 0.1 & 0.9 & 1.0 & 1.0 & 0.0 & 1.0 & 4.2 & 5.0 & 2.0 & 18.4 & 17.2 & 4.2 & 46.8 \\
\hline 16 & Fox Point & 0.9 & 1.3 & 3.1 & 3.6 & 2.2 & 2.3 & 1.3 & 14.7 & 19.1 & 7.4 & 20.8 & 13.9 & 3.8 & 65.0 \\
\hline 17 & Carney Point & 0.0 & 0.9 & 1.8 & 3.7 & 1.2 & 1.2 & 0.5 & 9.4 & 3.0 & 9.0 & 21.7 & 5.9 & 1.6 & 41.1 \\
\hline 18 & Deeves Beach & 0.6 & 2.2 & 6.5 & 5.0 & 9.5 & 7.4 & 8.0 & 39.2 & 4.3 & 14.4 & 47.6 & 40.9 & 29.6 & 136.8 \\
\hline 19 & Reedy Point & 0.6 & 0.4 & 0.8 & 1.1 & 1.3 & 0.7 & 0.0 & 4.8 & 4.2 & 1.9 & 8.0 & 3.1 & 0.8 & 18.1 \\
\hline 20 & Elfsborg & 0.6 & 0.0 & 0.0 & 0.1 & 0.2 & 0.0 & 0.0 & 0.8 & 0.9 & 0.4 & 8.1 & 11.0 & 1.1 & 21.9 \\
\hline 21 & Augustine Beach & 0.2 & 0.1 & 0.8 & 0.5 & 1.0 & 0.0 & 0.0 & 2.7 & 13.0 & 3.2 & 15.6 & 15.2 & 3.9 & 50.8 \\
\hline Delaware & Mean & 0.4 & 0.7 & 2.0 & 1.9 & 2.9 & 1.9 & 2.5 & 12.3 & 10.0 & 4.9 & 20.3 & 21.2 & 9.1 & 61.1 \\
\hline Delaware & Median & 0.4 & 0.4 & 1.0 & 1.1 & 1.2 & 0.7 & 0.5 & 4.8 & 6.8 & 3.2 & 18.4 & 17.2 & 3.9 & 50.8 \\
\hline EC-1, harbour sediment & Certificate Values & $\begin{array}{l}48.7 \\
( \pm 17)\end{array}$ & $\begin{array}{c}99.4 \\
( \pm 43.2)\end{array}$ & $\begin{array}{c}109.4 \\
( \pm 74.4)\end{array}$ & $\begin{array}{l}79.8 \\
( \pm 37.1)\end{array}$ & $\begin{array}{c}68.2 \\
( \pm 22.1)\end{array}$ & $\begin{array}{c}72 \\
( \pm 26.3)\end{array}$ & $\begin{array}{c}44.9 \\
( \pm 23.2)\end{array}$ & 522 & & & & & & $\begin{array}{l}2000 \\
( \pm 50)\end{array}$ \\
\hline \multirow[t]{2}{*}{ EC-1, harbour sediment } & Value obtained $(n=22)$ & $\begin{array}{l}40.0 \\
( \pm 6.3)\end{array}$ & $\begin{array}{c}94.6 \\
( \pm 5.4)\end{array}$ & $\begin{array}{l}103.2 \\
( \pm 4.2)\end{array}$ & $\begin{array}{c}93.2 \\
( \pm 11.9)\end{array}$ & $\begin{array}{c}82.3 \\
( \pm 7.9)\end{array}$ & $\begin{array}{c}83.8 \\
( \pm 9.1)\end{array}$ & $\begin{array}{c}57.4 \\
( \pm 5.3)\end{array}$ & $\begin{array}{l}555 \\
( \pm 50)\end{array}$ & & & & & & $\begin{array}{c}1869 \\
( \pm 167)\end{array}$ \\
\hline & LoQ & 1.4 & 1.3 & 1.2 & 1.1 & 1.1 & 1.2 & 1.5 & 0.0 & & & & & & 6.4 \\
\hline
\end{tabular}

PEC (MacDonald et al., 2000) 


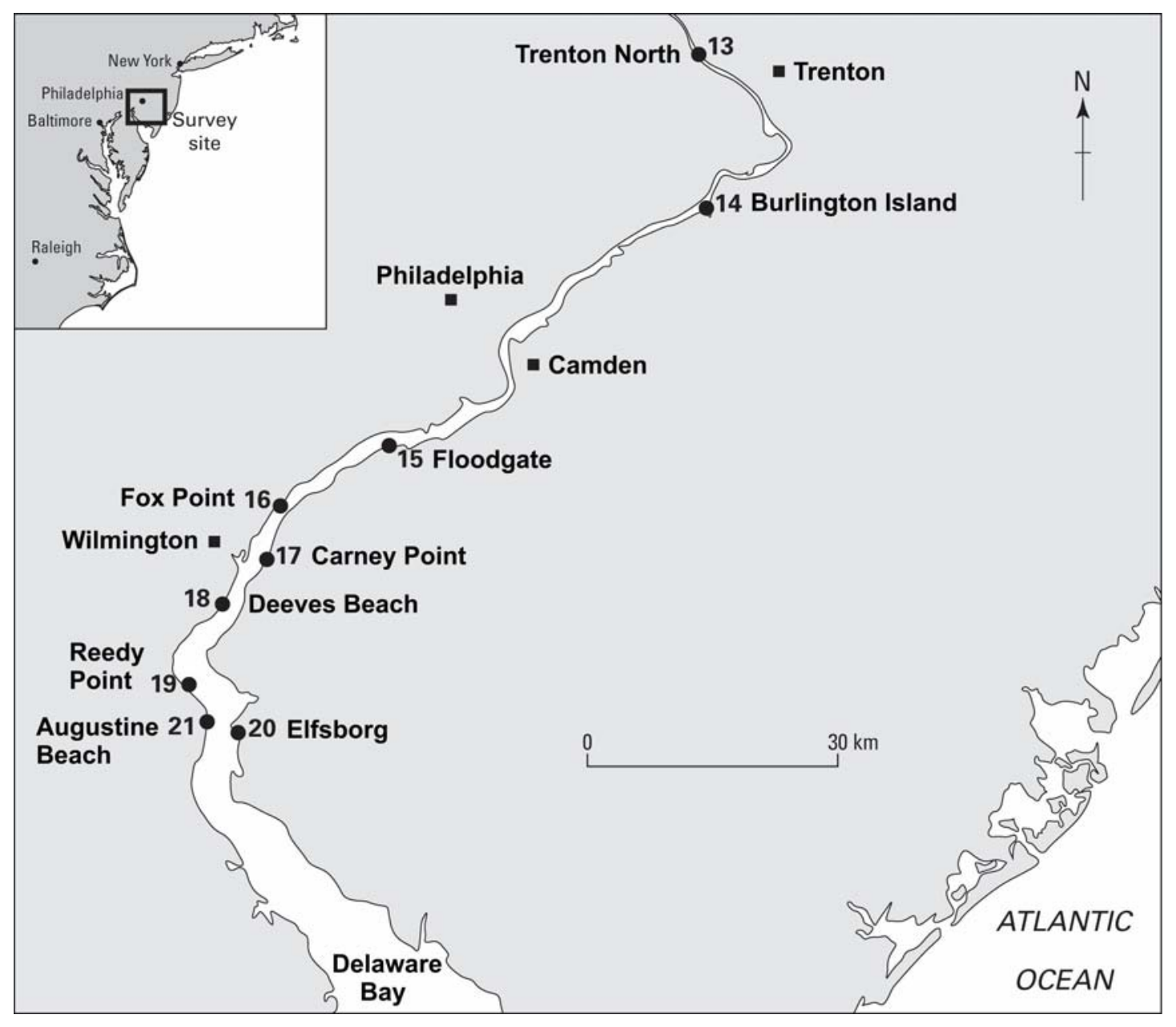

Fig. 1. Map showing locations of sample sites in of the Delaware River Estuary, USA. 


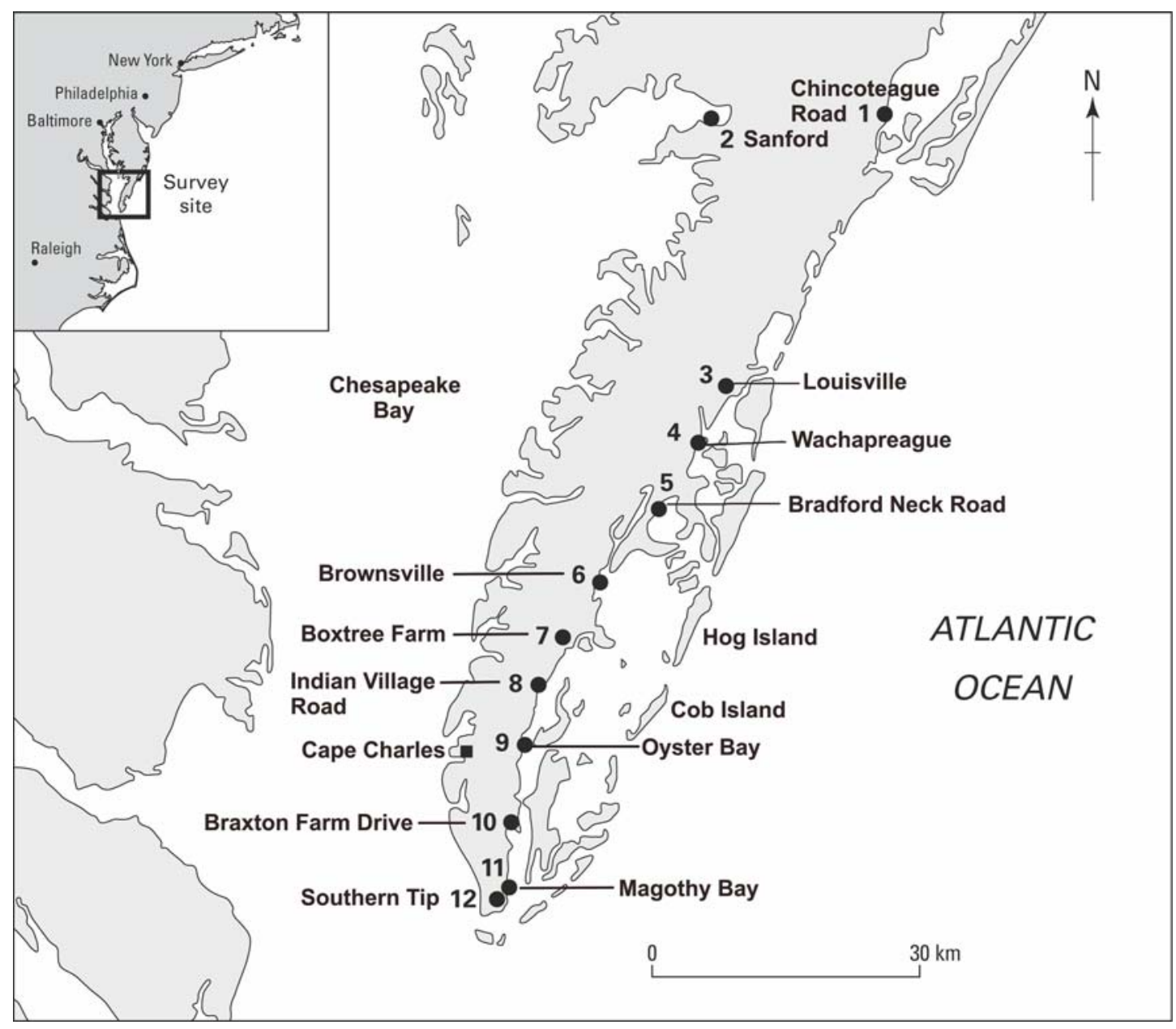

Fig. 2. Map showing locations of sample sites in of the Delmarva Peninsula, Virginia USA. 


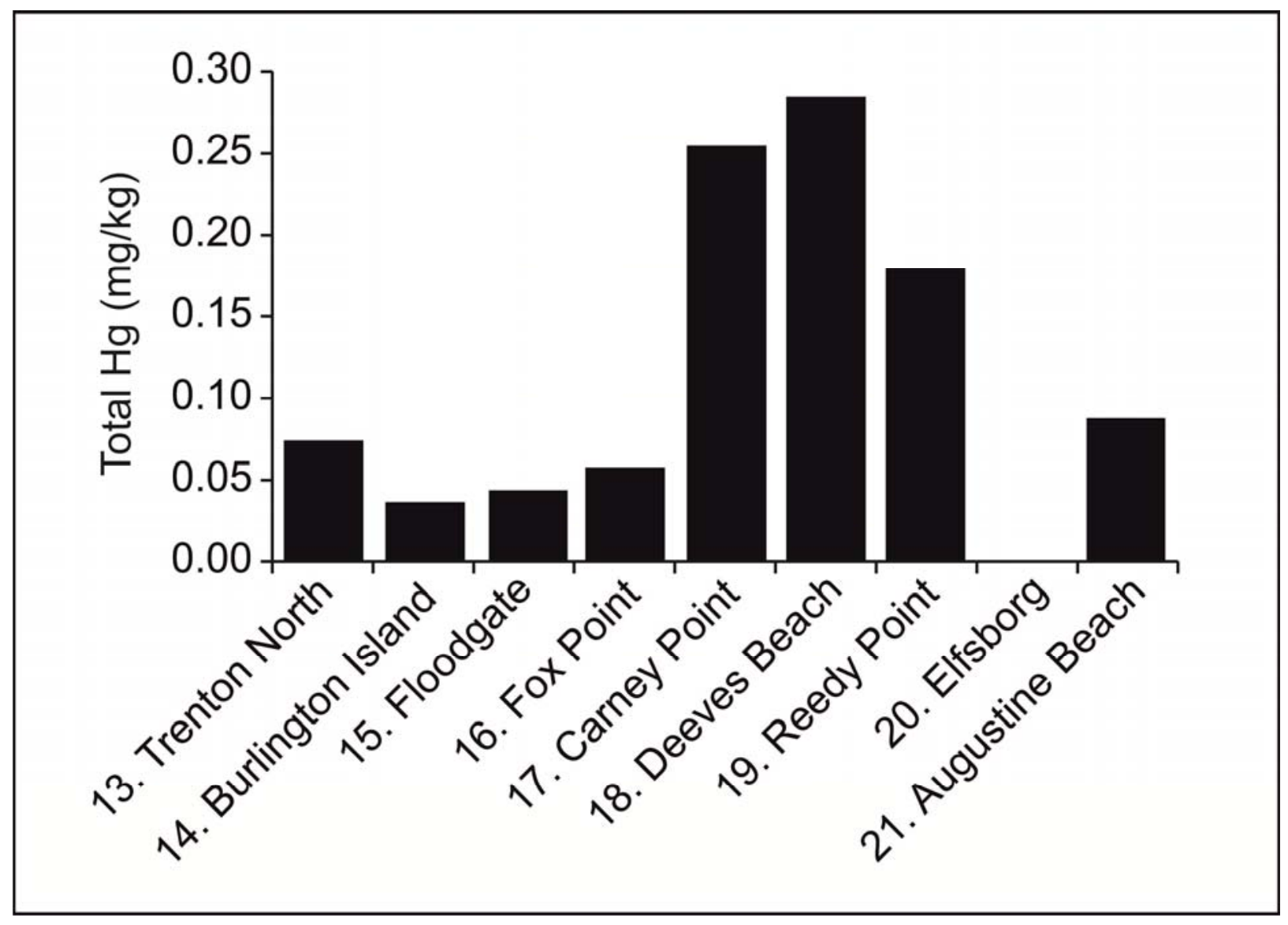

Fig. 3. Spatial distribution of $\mathrm{Hg}$ in surface sediments of the Delaware River. 

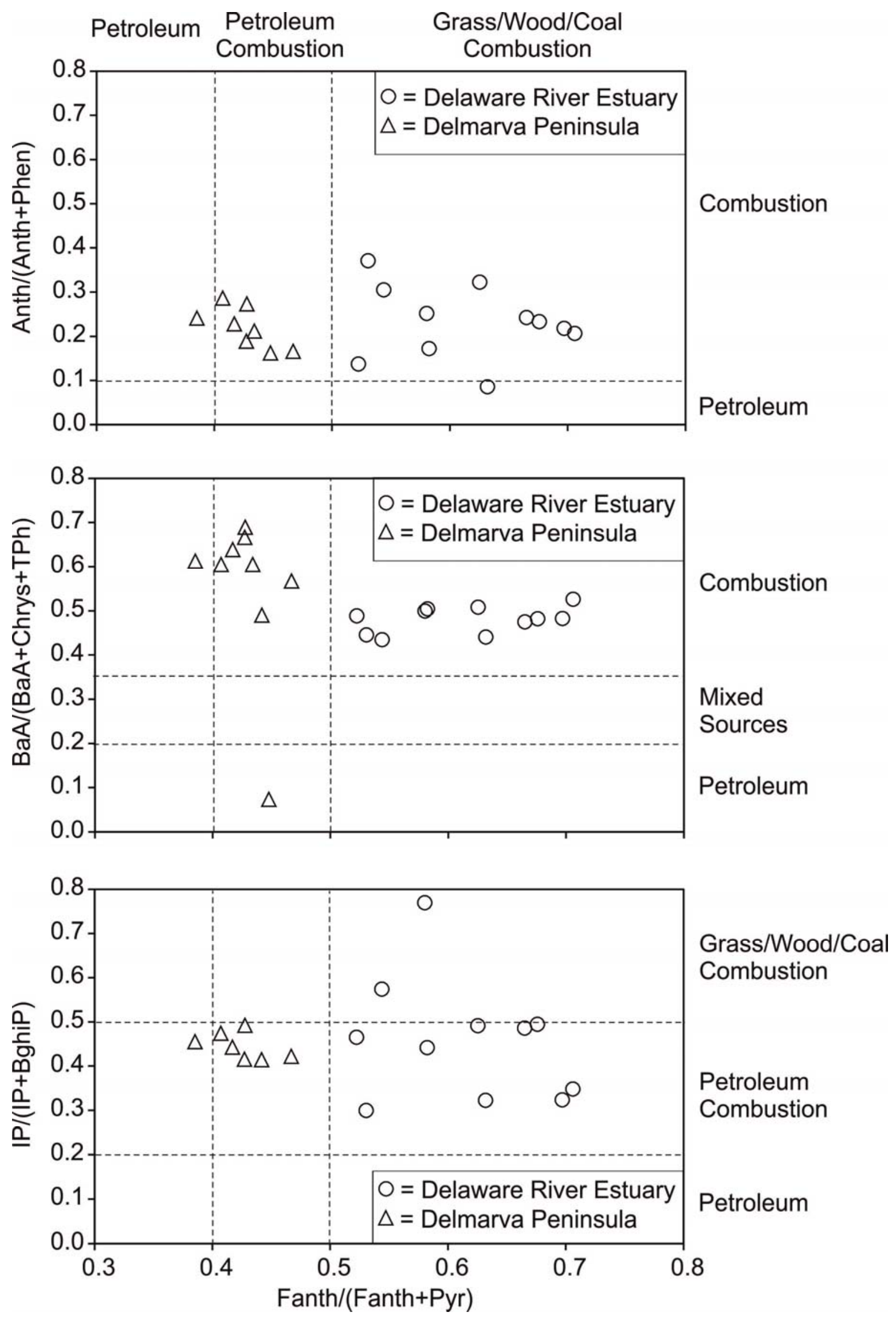

Fig. 4. PAH isomeric plot for surface sediments from the Delmarva Peninsula (circles) and Delaware River Estuary (triangles). 


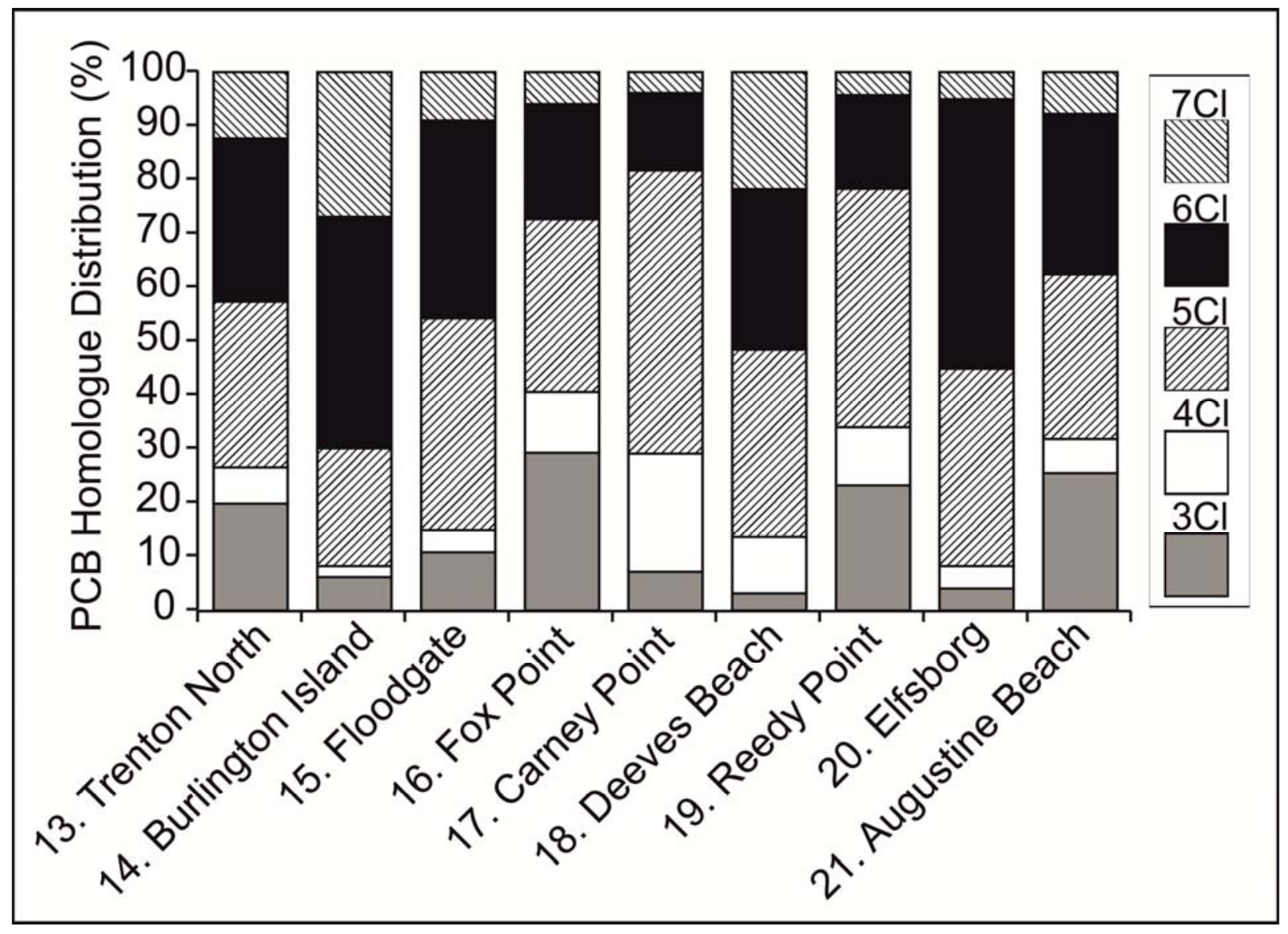

Fig. 5. Spatial variation of the relative contribution of PCB homologues for surface sediments from the Delaware River Estuary. 